\title{
Learning Motivation of Peripheral University Students and its Relation with their English Grades
}

Teuku Azhari

Chemical Engineering Department, Universitas Malikussaleh, Lhokseumawe, Aceh, Indonesia

Ema Dauyah

English Department, University of Abulyatama, Aceh Besar, Aceh, Indonesia

\begin{abstract}
Purpose - The purpose of this paper is to examine the causational effect of both internal and external motivation with learning outcomes at a peripheral university in the province of Aceh. It also aims to evaluate which of the two factors possess stronger impact on the other across different genders.

Design/Methodology/Approach - The model of research utilizes quantitative approach. Using the questionnaires as data gathering methodology, it is designed to understand aspects of both internal and external motivation which influences the results. Correlational information was then derived from the data using SPSS software. Then, data were elaborated for more detail and ease of reading for readers.

Findings - The results obtained from this research showed that there was no relationship between both internal and external motivation with students grades. Claiming to have relatively high motivation, still students failed to attain good grades. Observed individually, no apparent relationship was visible from each aspect. The finding also suggested that there was no difference impact was visible across different gender. Both genders, male and female, in this university did not show any significant correlation between motivation and grades.

Research limitations/Implications - Unlike many findings on similar studies, the research found out that motivation cannot be utilized as predictor to predict grades in the peripheral university. New approaches should be developed to find out working predictors for students grades.

Practical Implications - To understand influencing aspects for students' grades attainment, more and or other variables should be utilized. Both internal and external motivation factors failed to predict students' grades.

Originality/Value - Research on students learning motivation specifically at peripheral university was much been studied.
\end{abstract}

Keywords Peripheral University, intrinsic motivation, extrinsic motivation, English class performances

All papers within this proceedings volume have been peer reviewed by the scientific committee of the Malikussaleh International Conference on Multidisciplinary Studies (MICoMS 2017).

(C) Teuku Azhari, Ema Dauyah. Published in the Emerald Reach Proceedings Series. Published by Emerald Publishing Limited. This article is published under the Creative Commons Attribution (CC BY 4.0) licence. Anyone may reproduce, distribute, translate and create derivative works of this article (for both commercial and non-commercial purposes), subject to full attribution to the original publication and authors. The full terms of this licence may be seen at http://creativecommons.org/ licences/by/4.0/legalcode

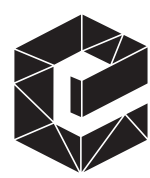

Emerald Reach Proceedings Series Vol. 1 pp. $473-478$ Emerald Publishing Limited DOI $10.1108 / 978-1-78756-793-1-00028$ 


\section{Proceedings of 1 . Introduction}

MICoMS 2017 Motivation is considerably significant feature that educationalists target to advance learning. Experts have had a long discussion about the association between motivation and language learning. (Lin and Warschauer, 2011; Tremblay and Gardner, 1995) stated that "The concept of language learning motivation has become a central component of a number of L2 acquisition." Gardner's social psychological approach has been widely utilized until late 1990s. Even believed as separate entities, (Covington and Mueller, 2001) "Motivation provides the primary impetus to initiate learning (Deci, Koestner, and Ryan, 2001) the L2 and later the driving force to sustain the long and often tedious learning process" (Dornyei, 1998). Research also indicated that those with higher motivation are more successful and efficient in their learning (Soureshjani, 2011).

Motivation has been highly linked to Tremblay, Gardner, Dornyei, etc. Gardner proposed three major constructs toward understanding motivation: (a) integrative motives, (b) attitude motives, and (c) socio-educational motives (Dornyei, 2009). Dornyei (1998) perceives motivation as a process and an explanation of behavior; "a mental processes that lead to the initiation and maintenance of action" and has shifted from stimuli and reinforcement contingencies and instead emphasizes on learners.

Motivation determines learners' degree of involvement in L2 learning. It is, therefore, without sufficient motivation, one will not exert their maximum capacity in language achievement (Leila Anjomshoa, 2015). One prominent view on motivation was intrinsic and extrinsic (Dornyei, 2009). Angraini (2011) divided factor of motivation into two: internal and external factors. She further proposed internal factor such as the motivation toward the knowledge to study and orientation to attend college. These two widely are known and wellused terms that have been in central attention of many researchers. Motivation ties hand in hand with feeling and emotion (Powell, 2005; Gheisari, 2017) and shift from classroom condition toward utilitarian, thus reducing teacher factor in the process (Nikolov, 1999). Often perceived as separated entities, recent views recognize them as combined factors, selfdetermination (Dornyei, 1998).

This research paper aimed to evaluate motivation in a deeper sense. Researcher aimed at analyzing how motivations impact the study of a language in student. The study was undertaken to answer three main questions: (i) do intrinsic and extrinsic motivation have positive influence on students the performance in English, (ii) which of the two provide stronger influence on performance, and (iii) does it have different effect across the gender.

To answer the research questions, questionnaires are distributed to 50 students at Universitas Abulyatama Aceh Besar. The questionnaires were designed in Likert scale which composed of 5 demographic questions, 20 questions on intrinsic motivation, and 30 questions on extrinsic motivation. Data finding was then processed using SPSS software to observe the regression of each aspect of the motivation. The questionnaires were designed under the hypotheses that they all contribute to students' achievement including on English grade.

\section{Methods}

Adopting Anggraini's model of motivation, researcher then formulated questionnaires to find the data needed in this research. These model questionnaires analyze internal and external elements in formulating one's English language learning motivation.

The questionnaires comprise of three: (i) background information, (ii) intrinsic motivation, and (iii) extrinsic motivation. Pearson's test indicated that the questionnaires were significant $(0.06)$ and, therefore, may be used. 


\subsection{Sample and population}

Population of this study was peripheral universities in Aceh. Researcher nominated University Abulyatama (Unaya, Aceh Besar) as the sample as it goes with study criteria. The university is situated at city outskirt, but is accessible easily. Adopting stratified random sampling, questionnaires were distributed randomly across gender, semester and major.

To analyze the data, SPSS software was used. Here, we converted data, run descriptive statistics, regression, and ANOVA. Regression was selected to evaluate if Independent variables (intrinsic and extrinsic motivation), variable $X$, impact positively on the dependent variable (English Grade), variable $Y$. ANOVA test was castoff to study if both predictors have impact toward the grade. We also analyze separately from gender point of view to understand if the result is the same across different gender.

\section{Results}

First stage was data transformation. Researcher then run one sample statistic test to study the significant of both IM and EM categories. It was later found out that both of the categories are statistically significant $(0.00)$.

Histogram charts in Figure 1 elaborate the distribution of students' response from each aspect, IM and EM. In IM chart, the distribution relatively packed in the middle (3.5-4.5). Meanwhile, on the EM chart, the response is distinctly high at center of the graph, 3.8, and formed a well-distributed curve for the others.

$R^{2}$ in Table 1 indicated that the model was accounted for $57 \%$ (0.57). This means that IM and EM can only predict $57 \%$ of the result. Forty-three percent of others, however, are not covered by this model. However, there is a huge gap between $R^{2}$ and adjusted $R^{2}(57 \& 4)$. Even though the model is proven to be statistically significant, internal issues might occur which drastically reduced the significance of the model. Regression analysis shows that
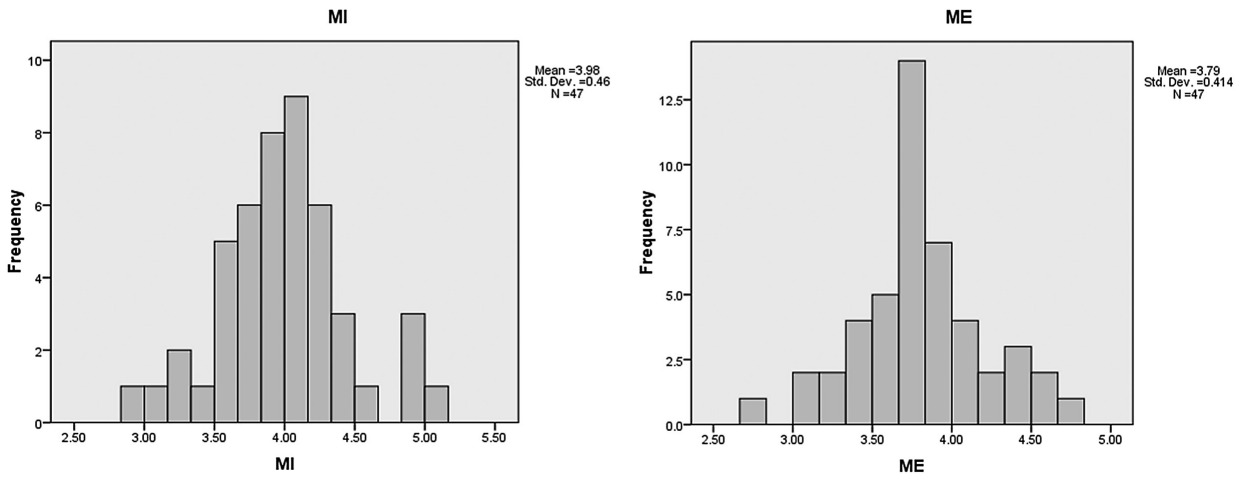

Figure 1. Distribution of Responses by

\begin{tabular}{|c|c|c|c|c|c|}
\hline Model & $R$ & $R^{2}$ & Adjusted $R^{2}$ & Std. Error of the Estimate & Table 1 \\
\hline 1 & $0.238^{\mathrm{a}}$ & 0.057 & 0.004 & 0.55837 & ANOVA Test \\
\hline
\end{tabular}


Proceedings of MICoMS 2017

\section{6}

both IM and EM have no significance and influence over dependent variables. With both of the score above 0.05, both aspects provided no significance towards English grades.

Finally, ANOVA test resulted in high score (0.350). The coefficient level from the test also yielded high score. Running regression test for each sub-aspect separately, interestingly enough, yielded a different result. One sub-aspect, quality of lecturer, is proven to be significant to predict student English grade. The rest, four others, are proven not statistically significant. When compared between gender and grade, it was found that no significant correlation occurred. The correlation was negative.

Findings also showed that students' English grade varied one to another. Of 47 respondents, 39 students gave up their grades, while 9 others did not. From these valid input, it was found that 13 students $(27.7 \%)$ got A, 24 students $(51.1 \%)$ got B, and 2 students $(4.3 \%)$ got $\mathrm{C}$. This showed us that, on an average, students managed to score B in English class.

\section{Discussion}

The pattern used in this study indicated $57 \%$ reliability. The remaining gap, which also influenced the grades, was not covered here. Other test results, ANOVA, signposted low correlation thus degrading the fact that internal and external factors do influence students' grades in English subject.

We predict that social environment such as parental support, social status, friends, and target essential to consider these factors in the future research. Language culture may also be responsible for students' grade achievement.

Of all sub-question, five sub-questions, only sub-question number 4 which is lecturer quality that has positive correlation with students' English grade. The rest, four others, are proven not statistically significant. These were actually contrary to the previous beliefs that the five sub-questions contributed positively to student' achievement.

Evaluated as two separate items, it was found that neither IM nor EM contributed positively to English grade achievement. Results indicated that all predictors failed to detect the cause. Majority respondents believed that they have high intrinsic motivation, as specified in the histogram graph. However, these were not apparent in their grades.

Running frequency test on English grades, I found that most students got B (51.1\%), about half got A (27.7\%), and last two students, however, got C. English does not seem to be favorite class for many students, or at least not their best at. Only one-third (1/3) achieved best grades while others did not. Gender, lastly, does not have any strong correlation with grade. This is to say that gender does not provide significant information to determine students' grade, especially in English. Thus, this cannot be taken as predictor for students' English grades.

\section{Conclusion}

Findings from this study showed us that the pattern used in this study failed to determine peripheral university students' motivation which influenced their grades in English subject. The model questions cannot be used as determiners. No significance was found at any level of observations, including the intrinsic (Deci et al., 2001). When observed as a single item, however, lecturer quality has significant and positive impact on grade achievement. Quality of lecturer yielded a positive impact on learning motivation and grades. Even though female developed a higher level of motivation compared with their male counterparts, it did not contribute to their final grades.

Arguably, the case may be caused by in-comprehensive model proposed in the study where more sub-items need to be included. These items are social environment and target 
language culture. Besides, students' intake may also be the culprit. This study therefore cannot be generalized to all universities in Aceh. More study and samples needs to be done

\section{References}

Angraini, I.S. (2011). Motivasi Belajar dan Faktor-Faktor yang Berpengaruh: Sebuah kajian pada Interaksi Pembelajaran Mahasiswa. Prodi Ekonomi Universitas Negeri Malang, Malang.

Covington, M.V. and Muleller, K.J. (2001). "Intrinsic Versus Extrinsic Motivation: An Approach/ Avoidance Reformulation”. Educational Psychology Review, Vol. 13, No. 2, pp. 157-176.

Deci, E., Koester, R. and Ryan, R.M. (2001). "Extrinsic Rewards and Intrinsic Motivation in Education: Reconsidered Once Again”. Review of Education Research, Vol. 71, No. 1, pp. 1-27.

Dornyei, Z. (1998). "Motivation in Second Language Learning”. Language Teaching, Vol. 31, pp. 117135.

Gardner, R.C. (2007). "Motivation and Second Language Acquisition”. Porta Linguarum, No. 8, pp. 9-20.

Gheisari, N. (2017). "Private Speech in Teacher-Learner Interaction in an EFL Context: A Sociocultural Perspective”. Iranian Journal of Language Teaching Research, Vol. 5, No. 2, pp. 53-74.

Howard, J. and Klein, R.A. (2006). "Motivation to Learn and Course Outcomes: The Impact of Delivery Mode, Learning Goal Orientation, and Perceived Barriers and Enables”. Personnel Psychology, Vol. 59, pp. 665-702.

Jung Zhang, X. (2006). "Language Learning Strategies, Motivation and EFL Proficiency: A Study of Chinese Tertiary-Level Non English Majors". Asian Englishes, pp. 20-47.

Lin, C., and Warschauer, M. (2011). Integrative versus Instrumental Orientation among Online Language Learners Orientação Integrativa versus Instrumental entre aprendizes on-line de língua. Linguagens E Dialogos, Vol. 2, No. 1, pp. 58-86.

Leila Anjomshoa, F.S. (2015). "The Importance of Motivation in Second Language Acquisition". International English Language and Literature, Vol. 3, No. 2, pp. 126-137.

Mahadi, T.S.T. and Jafari, S.M. (2012, December). "Motivation, Its Types, and Its Impact in Language Learning". International Journal of Business and Social Science, Vol. 3, No. 24, pp. 230-235.

Muna, I. (2008). Studi Perbandingan Pengajaran Ketrampilan Berbicara antara Bahasa Arab dan Bahasa Inggris dan di Madrasah Aliyah Sunan Pandan Aran Ngaglik Sleman Yogyakarta. Fakultas Tarbiyah Universitas Islam Negeri Sunan Kalijaga, Yogyakarta.

Nikolov, M. (1999, March). "Why Do They Learn English? Because the Teacher is Short. A Study of Hungarian Children's Foreign Language Learning Motivation”. Language Teaching Research, Vol. 3, No. 1, pp. 33-56.

Powell, S. (2005). "Apathy and Attitude: A Study of Motivation in Japanese High School Students of English”. Asian Englishes, pp. 46-63.

Prasetyo, H. (2012). "Faktor-Faktor yang Berpengaruh terhadap Motivasi Belajar". Available: www. sainsjournal.com: http://sainsjournal-fst11.web.unair.ac.id/artikel [accessed 14 October 2015].

Pujadi, A. (2009). Motivasi Belajar dan Faktor-Faktor yang Berpengaruh: Studi Kasus pada Fakultas Ekonomi Universitas Bunda Mulia. Fakultas Ekonomi Universitas Bunda Mulia, Jakarta.

Rebecca, L. and Oxford, P. (2003). "Language Learning Styles and Strategies, an Overview”. Learning Styles \& Strategies/Oxford, GALA, pp. 1-25.

Ripple, R.E. (1965). “Affective Factors Influences Classroom Learning”. Educational Leadership, pp. 476-532.

Tremblay, P.F. and Gardner, R.C. (1995). "Expanding the Motivation Construct in Language Learning". The Modern language Journal, Vol. 79, pp. 505-518.
Motivation of Peripheral University Students 
Proceedings of Wahyono, B. (2012). Pendidikan Ekonomi. Available: http://www.pendidikanekonomi.com/2012/10/ MICoMS 2017 faktor-faktor-yang-mempengaruhi.html [accessed 14 October 2015].

$\mathrm{Xu}, \mathrm{X}$. (2011). "The Relationship between Language Learning Motivation and the Choice of Language Learning Strategies Among Chinese Graduates". International Journal of English Linguistics, Vol. 1, No. 2, p. 203.

Yusuf, H. (2009). “Motivasi Pembelajaran Bahasa Inggris: Studi Kasus pada Mahasiswa Sastra Inggris UNISMA”. UNISMA, Malang.

\section{Corresponding author}

Teuku Azhari can be contacted at tazhari@unimal.ac.id 